\title{
Presence of two phylogenetically distinct groups in the deep-sea mussel Acharax (Mollusca: Bivalvia: Solemyidae)
}

\author{
Sven C. Neulinger ${ }^{1}$, Heiko Sahling ${ }^{2}$, Jörg Süling ${ }^{1}$, Johannes F. Imhoff ${ }^{1, *}$ \\ ${ }^{1}$ Leibniz-Institut für Meereswissenschaften, IFM-GEOMAR, Düsternbrooker Weg 20, 24105 Kiel, Germany \\ ${ }^{2}$ Deutsche Forschungsgemeinschaft-Forschungszentrum Ozeanränder, Klagenfurter Straße, 28359 Bremen, Germany
}

\begin{abstract}
The family Solemyidae represents ancestral protobranch bivalves with the shallowwater genus Solemya and the deep-sea genus Acharax. All known members of this family host symbiotic sulfur-oxidizing bacteria in their gill filaments. Analysis of 18S rRNA gene sequences of Acharax specimens from methane-seeps off Makran (Pakistan), Java (Indonesia), the Aleutian Trench and off the Oregon, Costa Rica, and Peru margins revealed that Solemya spp. and Acharax spp. are well-separated genetically. This supports the current systematic distinction based on morphological criteria. We found 2 clearly distinct clusters within the genus Acharax, with specimens from the Makran, Oregon and Peru (MOP) margins in one (MOP-Acharax) cluster, and those from Java, the Aleutian Trench and Costa Rica (JAC) in the other (JAC-Acharax) cluster. The separation of MOP- and JAC-Acharax clusters from each other and from Solemya (S. reidi and S. velum) is wellsupported by phylogenetic calculations employing maximum likelihood and maximum parsimony. Compared to genetic distances among other protobranch groups, distances between the MOP- and JAC-Acharax clusters would justify the affiliation of these clusters to separate species. This implies that species differentiation in Acharax based on shell morphology is likely to underestimate true species diversity within this taxon. Furthermore, our results support the hypothesis that genetic separation of Solemya and Acharax is congruent with the phylogeny of their bacterial endosymbionts.
\end{abstract}

KEY WORDS: Bivalvia $\cdot$ Solemyidae $\cdot$ Acharax $\cdot$ Solemya $\cdot$ Molecular phylogeny $\cdot 18 \mathrm{~S}$ rRNA gene $\cdot$ Endosymbionts $\cdot$ Sulfur-oxidizing bacteria

\section{INTRODUCTION}

The family Solemyidae is a group of ancestral protobranch bivalves, and when in conjunction with the family Manzanellidae forms the superfamily Solemyoidea. As far as is known, all species of the Solemyidae live in symbiosis with chemoautotrophic sulfur-oxidizing bacteria, on which they depend to varying degrees (Fisher 1990). Some species lack an alimentary canal completely (Bernard 1980). Solemyid bivalves are cosmopolitan. The genus Solemya is generally found at continental-shelf and upper-slope depths (0 to $600 \mathrm{~m})$, while the genus Acharax is found deeper, at depths from $\sim 400 \mathrm{~m}$ on the continental slope to the deepest sites on the slope of the Japan Trench at $5379 \mathrm{~m}$
(Kuznetsov \& Schileyko 1984, Métivier \& von Cosel 1993, Coan et al. 2000, Okutani \& Fujikura 2002).

The genus Solemya lives in sediments with high organic-matter content, often at reduced oxygen concentrations. Hydrogen sulfide is frequently present due to sulfate reduction coupled with organic matter degradation (Conway et al. 1992). After the discovery of the symbiotic chemoautotrophic bacteria, numerous studies of Solemya enlightened the physiology of the symbiosis (Cavanaugh 1983, Felbeck 1983, Powell \& Somero 1986, Anderson et al. 1987, Cavanaugh et al. 1988, O'Brien \& Vetter 1990, Vetter 1990, Wilmot \& Vetter 1992, Lee \& Childress 1994) as well as the phylogeny and transmission of the endosymbionts (Gustafson \& Reid 1988, Eisen et al. 1992, Cary 1994, 
Distel et al. 1994, Krueger et al. 1996a,b, Krueger \& Cavanaugh 1997).

In contrast, the genus Acharax, which lives buried in reducing sediments, has rarely been taken alive, and information on its phylogenetic position and diversity is lacking. Recovery or observations of the characteristic thick periostracum was often the only evidence for the presence of this genus. During this study, we recovered living specimens from methane seeps in the Indian Ocean off Pakistan (von Rad et al. 2000) and off Indonesia (Wiedicke et al. 2002), as well as in the Pacific Ocean in the Aleutian Trench (Suess et al. 1998), at Hydrate Ridge off Oregon (Sahling et al. 2002), and off Costa Rica and Peru (H. Sahling unpubl.). Hydrogen sulfide was present at these sites, reaching concentrations of up to $300 \mu \mathrm{M}$ in the upper $25 \mathrm{~cm}$ at Hydrate Ridge (Sahling et al. 2002). The genus Acharax was also found at other Cold Seep locations (see review by Sibuet \& Olu 1998) and in sediments influenced by hydrothermal venting (Juniper et al. 1992, Métivier \& von Cosel 1993). Furthermore, the periostracum was frequently found in compacted clay substrata along the western North American coast (Coan et al. 2000). Acharax spp. apparently exploit deep-sea habitats, in which sulfide is present.

The genus Acharax differs morphologically from Solemya in having an external ligament set on a narrow nymph (Coan et al. 2000). However, at a first glance both solemyids appear so similar that specimens discovered at various deep-sea sites might have been misclassified erroneously as Solemya (see review by Sibuet \& Olu 1998). For example, re-examination of specimens from the Aleutian Trench and from sediments off Oregon revealed Acharax but not Solemya (as reported earlier: Suess et al. 1985, Suess et al. 1998).

It was shown in a previous study with Acharax specimens from the same locations that this genus harbors sulfur-oxidizing bacteria in its gills (Imhoff et al. 2003). According to 16S rRNA gene-sequence analysis, these bacteria formed a new group of sulfur-oxidizing endosymbiotic Gammaproteobacteria. This group was separated from other known symbiotic bacteria, including the symbionts from Solemya species and from other solemyid and lucinid bivalves. The question arose as to whether the Acharax host, similar to its endosymbiotic bacteria, is clearly separated from its sister genus Solemya on a genetic basis, thereby giving support to a possible host-symbiont coevolution.

\section{MATERIALS AND METHODS}

Origin and denomination of bivalves. Specimens of Acharax spp. had been collected during several cruises of RV 'Sonne' from 6 different regions in the Indian and Pacific Ocean and stored at $-30^{\circ} \mathrm{C}$ (Table 1, Fig. 1). From the shell morphology (periostracum), all specimens were identified as belonging to the same species, most probably $A$. johnsoni. This was supported by experts on bivalve taxonomy (P. V. Scott and E. V. Coan pers. comm.). A representative assortment of Acharax specimens, including representatives of MOP-Acharax and JAC-Acharax clusters, collected at the same sites as the individuals investigated in this study, was deposited under Accession No. 2003-039 at the Santa Barbara Museum of Natural History, USA.

DNA extraction, amplification and sequencing. Bivalve DNA was extracted from the foot (A1 Peru from the mantle) using QIAGEN® Genomic-tip 20/G (QIAGEN) with the Genomic DNA Buffer Set (QIAGEN). Primers for amplification and sequencing of bivalve 18S rDNA were designed using complete molluscan 18S rDNA sequences from the EMBL nucleotide sequence database (Stoesser et al. 2003). For detection of suitable priming regions, these sequences were aligned with the program ClustalX Version 1.81 (Thompson et al. 1997) using default parameters (gap-opening penalty= 15; gap-extension penalty $>6.66$ ). Primer synthesis was accomplished by MWG Biotech. Polymerase chain reaction (PCR) was conducted by use of puReTaq ${ }^{\mathrm{TM}}$ Ready-To-Go ${ }^{\text {TMPCR }}$ Beads (Amersham Biosciences) in a Progene ${ }^{\circledR}$ thermocycler (Techne) with Primers 5'GCCAGTAGCATATGCTTG TCTC-3' (forward from Position 9 in the sequence of Solemya reidi) and 5'CCTTGTTACGACT TTTAC-3' (reverse from Position 1782 in the sequence of $S$. reidi). The anticipated size of the PCR product was about 1770 nucleotides (nt). Cycling conditions were 40 cycles in the following pattern: $40 \mathrm{~s}$ at $91^{\circ} \mathrm{C}$ for denaturing, $40 \mathrm{~s}$ at $50^{\circ} \mathrm{C}$ for

Table 1. Acharax spp. Collection data of specimens examined. Denomination: A (for Acharax), individual identification no., sampling region; SO: RV 'Sonne', TVG: TV-guided grab

\begin{tabular}{|c|c|c|c|c|c|}
\hline Denomination & Cruise & Year & Position & $\begin{array}{c}\text { Depth } \\
\text { (m) }\end{array}$ & Stn \\
\hline A1-Oregon & SO 143 & 1999 & $44^{\circ} 34.2^{\prime} \mathrm{N}, 125^{\circ} 08.8^{\prime} \mathrm{W}$ & 780 & TVG 71-2 \\
\hline A2-Oregon & SO 143 & 1999 & $44^{\circ} 40.2^{\prime} \mathrm{N}, 125^{\circ} 03.3^{\prime} \mathrm{W}$ & 910 & TVG $40-2$ \\
\hline A8-Oregon & SO 143 & 1999 & $44^{\circ} 34.2^{\prime} \mathrm{N}, 125^{\circ} 08.8^{\prime} \mathrm{W}$ & 780 & TVG 56-1 \\
\hline A10-/A13-Oregon & SO 143 & 1999 & $44^{\circ} 40.2^{\prime} \mathrm{N}, 125^{\circ} 03.3^{\prime} \mathrm{W}$ & 910 & TVG $40-2$ \\
\hline A1-/A2-/A3-Java & SO 139 & 1999 & $7^{\circ} 57.5^{\prime} \mathrm{S}, 106^{\circ} 17.7^{\prime} \mathrm{E}$ & 2940 & TVG 91 \\
\hline A1-/A2-Makran & SO 130 & 1998 & $24^{\circ} 33.0^{\prime} \mathrm{N}, 64^{\circ} 15.6^{\prime} \mathrm{E}$ & 2220 & TVG 330 \\
\hline A5-Aleutian & SO 110 & 1996 & $54^{\circ} 18.2^{\prime} \mathrm{N}, 157^{\circ} 11.9^{\prime} \mathrm{W}$ & 4810 & TVG 43 \\
\hline A1-Peru & SO 78 & 1992 & ca. $9^{\circ} 35^{\prime} \mathrm{S}$, ca. $80^{\circ} 07^{\prime} \mathrm{W}$ & ca. 3500 & Dredge 163 \\
\hline A3-Costa Rica & SO 163 & 2002 & $9^{\circ} 10.4^{\prime} \mathrm{N}, 084^{\circ} 48.2^{\prime} \mathrm{W}$ & 763 & TVG 3 \\
\hline
\end{tabular}




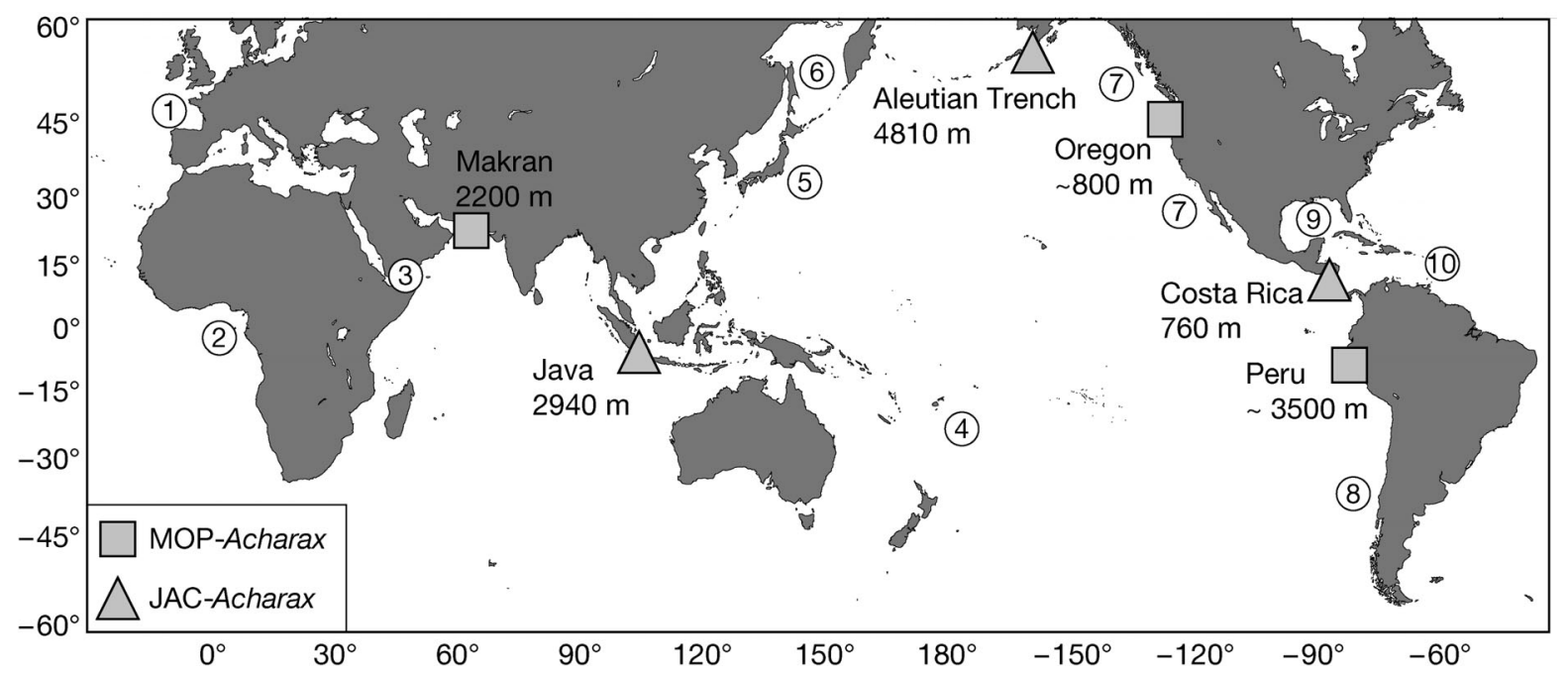

Fig. 1. Acharax spp. Global distribution of deep-sea solemyids. Locations and depths of Acharax specimens including those used in this study are indicated, as is their affiliation with the MOP (Makran, Oregon, Peru margins)-Acharax and JAC (Java, Aleutian Trench, Costa Rica)-Acharax clusters. Data from 1, 2: H. Sahling (unpubl.); 3: Kuznetsov \& Schileyko (1984, A. eremita); 4: Métivier \& von Cosel (1993, A. alinae); 5: Okutani \& Fujikura (2002); 6: Sahling et al. (2003); 7: Coan et al. (2000); 8: Sellanes et al. (2004); 9: Carney (1994); 10: Olu et al. (1997); Makran: von Rad et al. (2000); Java: Wiedicke et al. (2002); Aleutian Trench: Suess et al. (1998); Oregon: Sahling et al. (2002); Costa Rica and Peru margins: H. Sahling (unpubl.)

annealing, and $1.5 \mathrm{~min}$ at $72^{\circ} \mathrm{C}$ for elongation; the initial step was 2 min at $91^{\circ} \mathrm{C}$ for denaturing, the terminal steps were $40 \mathrm{~s}$ at $91^{\circ} \mathrm{C}$ for denaturing, $1 \mathrm{~min}$ at $40^{\circ} \mathrm{C}$ for annealing, and $5 \mathrm{~min}$ at $72^{\circ} \mathrm{C}$ for elongation. PCR products were purified using the QIAquick ${ }^{\circledR}$ PCR Purification Kit (QIAGEN). Cycle sequencing from PCR products was conducted with the ABI PRISM® BigDye $^{\mathrm{TM}}$ Terminator Cycle Sequencing Ready Reaction Kit Version 2.0 (Applied Biosystems) and suitable sequencing primers designed and synthesized as described above. Capillary electrophoresis was done on an ABI PRISM ${ }^{\circledR} 310$ Genetic analyzer (Applied Biosystems). We sequenced both strands of the 18S-rRNA gene to ensure data consistency. Sequence fragments were assembled with the program SeqMan $^{\mathrm{TM}}$ II Version 4.03 (DNASTAR).

Sequence alignment. For phylogenetic analysis, the sequences of our specimens were aligned together with additional sequences of other protobranch bivalves and the sequence of the scaphopod Antalis pilsbryi as outgroup (Table 2). Alignment was done with the program ARB (Ludwig et al. 2004). The $18 \mathrm{~S}$ rRNA secondary structure of Saccharomyces cerevisiae (Table 2) was used as guidance for manual alignment. Gap-only positions introduced by ARB and terminal parts with missing data were removed from the alignment with ClustalX, leading to a total length of the alignment of 1714 positions. The alignment is available from the corresponding author of this study.

Phylogenetic analysis. Maximum likelihood (ML) and maximum parsimony (MP) calculations were conducted with PAUP* Version 4.0 beta 10 Win (Swofford 2003). We employed the program Modeltest Version 3.7 (Posada \& Crandall 1998) to determine the most appropriate model of nucleotide substitution.

Table 2. 18S rRNA gene sequences from EMBL database used for phylogenetic calculations. Sequences for scaphopod Antalis (Dentalium) pilsbryi and baker's yeast Saccharomyces cerevisiae are shown for comparison. 18S rRNA gene sequences of Acharax deposited under EMBL Accession No. AJ563751 to AJ563763

\begin{tabular}{|lllc|}
\hline Taxonomy & \multicolumn{1}{c}{ Species } & $\begin{array}{c}\text { EMBL } \\
\text { Accession No. }\end{array}$ & $\begin{array}{c}\text { Sequence } \\
\text { length }\end{array}$ \\
\hline $\begin{array}{l}\text { Bivalvia, Protobranchia } \\
\text { Superfamily Solemyoidea } \\
\text { Family Solemyidae }\end{array}$ & $\begin{array}{l}\text { Solemya reidi } \\
\text { Solemya velum }\end{array}$ & AF117737 & 1806 \\
Superfamily Nuculoidea & AF120524 & 1771 \\
Family Nuculidae & Nucula sulcata & AF207642 & 1765 \\
Supula proxima & AF120526 & 176 \\
Family Yoldiidae & Yoldia myalis & AF207643 & 176 \\
Family Nuculanidae & Nuculana pernula & AY145385 & 181 \\
Family Neilonellidae & Neilonella subovata & AF207645 & 1770 \\
Scaphopoda & Antalis pilsbryi & AF120522 & 1804 \\
Fungi, Ascomycota & Saccharomyces & V01335 & 1798 \\
& cerevisiae & & \\
\hline
\end{tabular}


According to the Akaike Information Criterion (AIC) (Akaike 1974, Posada \& Buckley 2004), the model $\mathrm{TrN}+\mathrm{I}+\mathrm{G}$ provided the best fit to our data. Search for the optimal tree was performed by random stepwise addition with 1000 repetitions in ML and 1000000 repetitions in MP (gaps treated as 'missing'), with subsequent tree-bisection-reconnection (TBR). Bootstrap analyses were accomplished with 100 replicates in ML and 10000 replicates in MP, with 10 search repetitions per replicate in both cases.

\section{RESULTS}

\section{Maximum likelihood (ML)}

As shown in the ML tree (Fig. 2), the Solemyoidea (genera Solemya and Acharax) form a distinct sister group to the Nuculoidea (Nucula proxima, N. sulcata) and, together with the latter, a sister group to the Nuculanoidea (Nuculana pernula, Yoldia myalis, Neilonella subovata). The tree reveals a tripartition of the examined solemyid bivalves: (1) Solemya cluster: sequences of Solemya reidi and S. velum; (2) MakranOregon-Peru Acharax cluster (MOP-Acharax cluster): sequences of the specimens of Acharax spp. from the regions off Makran, Oregon, and from the Peru mar- gins; (3) Java-Aleutian-Costa Rica Acharax cluster (JAC-Acharax cluster): sequences of the specimens of Acharax spp. from the regions off Java and Costa Rica, and from the Aleutian Trench.

Sequence differences between Solemya reidi and $S$. velum were very small, and the branch of $S$. velum actually collapsed to zero by the tree calculation algorithm (branch length $\leq 10^{-8}$ substitutions per alignment position). All Acharax specimens form a group wellseparated from the Solemya cluster. JAC-Acharax in turn forms a well defined subcluster deriving from MOP-Acharax, showing a remarkably high difference to the other 2 solemyid clusters. The specimens from Makran exhibit considerably higher genetic differences than the other members of MOP-Acharax and are placed between the latter and JAC-Acharax.

\section{Maximum parsimony (MP)}

Results of MP calculations based upon 184 parsimony-informative characters yielded 5 equally parsimonious trees (not shown). All MP trees basically resembled the ML tree described above, as far as principle discrimination of clusters is concerned. The trees can be subdivided into 2 variants: in all trees, MOP-Acharax and JAC-Acharax are sister groups.

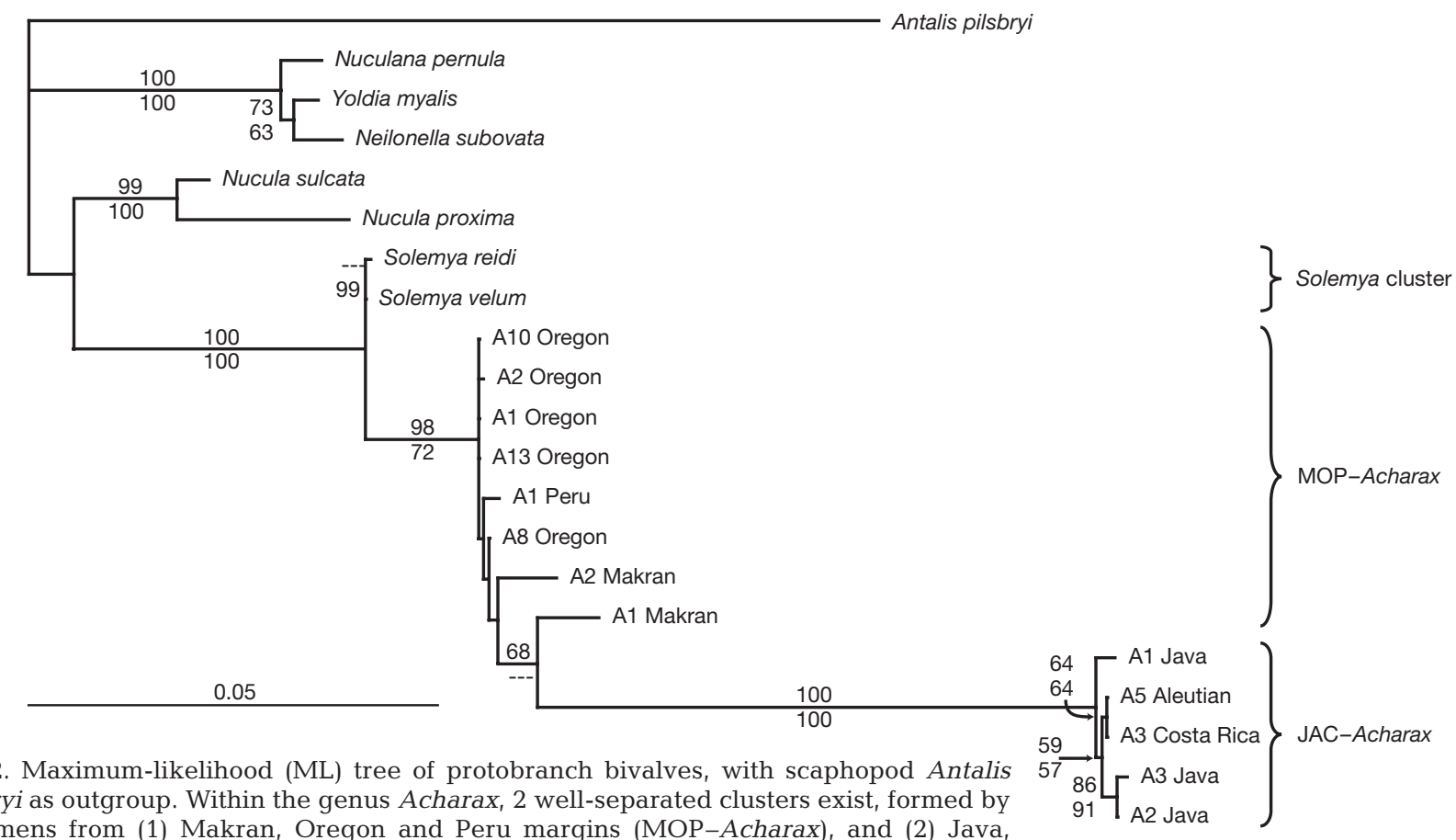
pilsbryi as outgroup. Within the genus Acharax, 2 well-separated clusters exist, formed by specimens from (1) Makran, Oregon and Peru margins (MOP-Acharax), and (2) Java, Aleutian Trench and Costa Rica (JAC-Acharax). Scale bar $=0.05$ substitutions per alignment position. Values on topology nodes: bootstrap proportions (BP) for both calculation methods, with ML above branch and MP (maximum parsimony) below branch; nodes lacking BP values did not occur in majority-rule tree of the relevant calculation method. Acharax specimen denominations as in Table 1 
The two variants differ in the position of A1-Makran, which clusters with JAC-Acharax in the second but not the first variant.

\section{Bootstrap proportions (BP)}

The BP values for the 2 phylogenetic methods are shown in Fig. 2. The clustering of taxa according to the superfamilies Nuculoidea, Nuculanoidea and Solemyoidea always shows highest agreement (99 to $100 \%$ ). Also, the groups of Solemya and Acharax were wellsupported by BP values between 72 and $99 \%$. Trifurcations of $S$. reidi, $S$. velum, and Acharax clusters occurred in most ML bootstrap replicates because of the zero branch length of $S$. velum. Thus an explicit $\mathrm{BP}$ value could not be assigned to the Solemya cluster by PAUP* for ML calculations. Separation of JACAcharax from MOP-Acharax is unequivocally supported by both methods ( $100 \%$ each). However, the common descent of JAC-Acharax and A1 Makran, as suggested by the ML calculations in Fig. 2, is only poorly supported ( $68 \%$ in ML), or not supported at all (MP). The main reason for this is the ambiguous placement of A1 Makran in single ML and MP bootstrap trees. Lower bootstrap support likewise applies to most relations within the 2 Acharax clusters.

\section{Hypervariable regions of $18 \mathrm{~S}$ rRNA}

The hypervariable regions of ribosomal nucleotide sequences are well-suited for comparison of closely related organisms, and were therefore visually inspected for signatures to establish groups and subgroups of the investigated species and specimens (Fig. 3). The comparison supported the tripartition of the examined solemyids established by sequence comparison. MOP- and JAC-Acharax clusters differ significantly, from each other and from Solemya in numerous indels (Fig. 3).

\section{DISCUSSION}

\section{Phylogeny of Solemyidae}

Comprehensive phylogenetic studies of bivalves including solemyids have been undertaken by numerous authors (Waller 1990, Steiner \& Müller 1996, Adamkewicz et al. 1997, Waller 1998, Steiner \& Hammer 2000, Giribet \& Wheeler 2002, Giribet \& Distel 2003, Campbell et al. 2004) who do not provide detailed information about the family Solemyidae. In particular, information on the genus Acharax is lacking. Therefore we have turned our attention to solemyids, with particular focus on Acharax. This genus has not been examined by means of molecular phylogeny so far, and its distinction from Solemya based on morphological properties is difficult.

In numerous studies, 18S rDNA has been used to analyze phylogenetic relationships of bivalves. The high degree of conservation of major parts of this gene allows the investigation of relationships between phylogenetically distant organisms, while highly variable regions of this gene also enable the distinction of closely related organisms. The results for the general phylogenetic relationships between the 3 protobranch

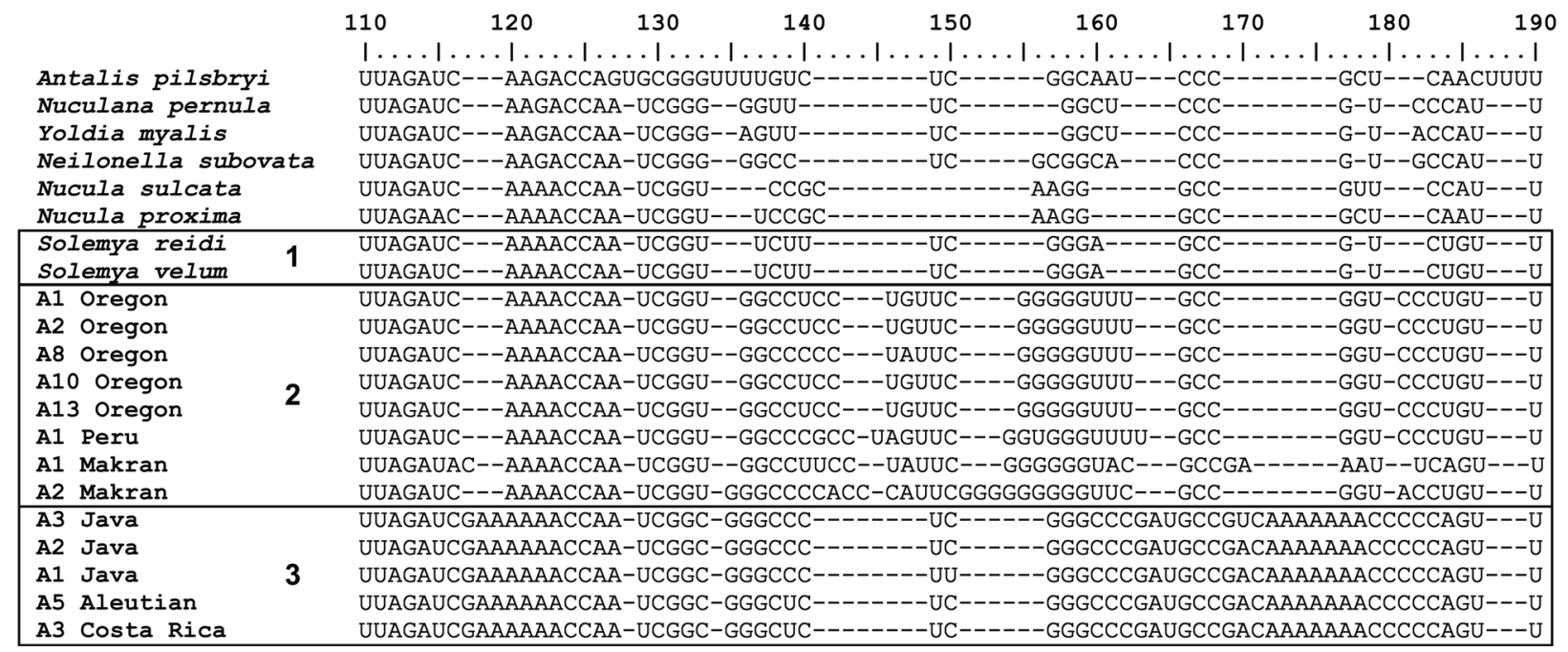

Fig. 3. Selected hypervariable region (Positions 115 to 189) of alignment, revealing clusters of solemyid sequences. 1: Solemya; 2: Acharax from Makran, Oregon and Peru margins (MOP-Acharax), 3: Acharax from Java, Aleutian Trench and Costa Rica (JAC-Acharax). Acharax specimen denominations as in Table 1 
superfamilies (Fig. 2) are in agreement with the phylogeny of protobranch bivalves as proposed by Giribet \& Wheeler (2002): the superfamily Solemyoidea represents a sister group to the superfamily Nuculoidea, both being well-separated from the superfamily Nuculanoidea. Since no 18S rDNA sequence data of Manzanellidae were available, we only considered the family Solemyidae. Within this family, the 2 genera Solemya and Acharax are clearly distinct from each other by their $18 \mathrm{~S}$ rDNA sequence divergence. These groups and their separation are well-supported by sequence distances and the tree configuration (as demonstrated by ML and MP methods), and by high bootstrap proportions of these calculations (Fig. 2). This finding supports the current systematic distinction based on morphological criteria (Coan et al. 2000).

Because differences between closely related organisms are best resolved in the highly variable regions of ribosomal rDNA, we have included these in our considerations. Signatures of the nucleotide patterns from hypervariable regions (Fig. 3) give additional support to the separation of the groups of solemyid bivalves considered.

\section{Two clusters of deep-sea solemyids}

Within the genus Acharax, 2 well-separated clusters were formed by specimens from the Makran, Oregon and Peru margins (MOP-Acharax) on the one hand, and from Java, the Aleutian Trench and Costa Rica (JAC-Acharax) on the other. The partitioning of MOP- and JAC-Acharax are verified by both treebuilding methods and bootstrap calculations. Ambiguities are evident in the placement of A1 Makran with regard to its different positioning in the MP topologies and in the ML and MP bootstrap calculations. We rate these ambiguities together with the intermediate branch lengths of A1 and A2 Makran as indications for their transient position between MOPand JAC-Acharax.

The large differences in 18S rRNA gene sequences found between the Acharax clusters are unexpectedly high for members considered to belong to the same species. They are manifested in addition by several sequence signatures characteristic for each of the clusters (Fig. 3). Comparison with distances in other protobranch groups (Fig. 2) indicates that sequence differences would easily justify the separation of the members of MOP- and JAC-Acharax clusters into separate species. We therefore propose that our specimens are representatives of at least 2 different species and do not all belong to A. johnsoni, as assumed previously. This also implies that shell morphology does not reflect the genetic diversity of
Acharax, and is likely to underestimate the true species diversity of this genus if used for species differentiation.

Factors that could have caused the strong separation of clusters within Acharax may include depth distribution, geochemical properties of the habitat and geographical separation: (1) While the genus Solemya (0 to $600 \mathrm{~m}$ ) appears to be separated from Acharax $(\sim 400$ to $5379 \mathrm{~m})$ by distribution in different water depths, both Acharax clusters have preferences for a large range of deep-water habitats, with specimens of the JAC-Acharax cluster being present over the largest range of depth (Table 1, Fig. 1). (2) Phylogenetic separation of the 2 Acharax clusters may reflect adaptation to different geochemical environments. Such correlations were shown for the vesicomyid clams Calyptogena pacifica and C. kilmeri, 2 species whose separation was associated with the different pore-water composition of their habitats (Barry et al. 1997). Apart from the fact that all Acharax specimens of this study were collected at or near methane-seeps, details about their geochemical environments are not available, and an ecological explanation for the observed separation of the 2 Acharax clusters requires further study. (3) Members of the 2 Acharax clusters were not found together at any of the sampling sites, which are geographically well-separated locations (Fig. 1). This indicates that geographic distribution differentiates among groups or species of Acharax, although geographic isolation itself is unlikely to explain the development into 2 different clusters: the specimens from Makran, a location well-separated from other sources of deep-sea solemyids (Fig. 1), are clearly distinguishable from the other members of MOP-Acharax (Fig. 2). Also, species that differ in morphology from the MOP- and JAC-Acharax clusters A. eremita in the Gulf of Aden (Kuznetsov \& Schileyko 1984), and A. alinae found in the Lau Basin (Métivier \& von Cosel 1993) - were not found at the locations of the present study (see locations 3 and 4 in Fig. 1).

The large phylogenetic distance of JAC-Acharax to the other solemyid clusters remains unexplained for the time being. Results from ML and MP calculations indicate that MOP- and JAC-Acharax have a common ancestor, and that JAC-Acharax is likely to have evolved from MOP-Acharax. Considering the sequence distances, it can be concluded that, once separated from the MOP-Acharax group, JAC-Acharax evolved much faster than the former. A possible explanation could be better adaptation of JAC-Acharax to the geochemical environment, faster growth and, in consequence, outcompeting of representatives of MOP-Acharax. Such mechanism would also explain why specimens of both clusters were not found together at the habitats investigated. 


\section{Comparison between host and symbiont phylogeny}

Comparing phylogenies of the Acharax hosts and their symbionts provides useful insights into the evolutionary history of the symbioses. Endosymbionts of Acharax form a new group of sulfur-oxidizing bacteria related to, but clearly distinct from, other known symbiotic sulfur-oxidizing Gammaproteobacteria (Imhoff et al. 2003). The Acharax endosymbionts form a separate branch related to symbiotic sulfur bacteria of Solemya and other host species including lucinid bivalves and vestimentiferan tubeworms. The present study has demonstrated that the host Acharax is also well-separated phylogenetically from the host Solemya. Thus, host and endosymbiont phylogeny are in agreement in this respect. However, the large differences between MOP- and JAC-Acharax are not reflected in the phylogeny of their symbionts (Imhoff et al. 2003), which may have evolved at a slower rate than their host species. The large evolutionary differences among hosts as well as among their endosymbionts are in accordance with the presumed ancient history of solemyids (Coan et al. 2000): the first solemyids appeared in the lower Ordovician ( 440 million yr BP), Acharax in the Permian or perhaps middle Devonian ( 225 to 280 million yr BP) and Solemya in the Jurassic (135 to 195 million yr BP). They are also in accordance with the hypothesis of an ancient uptake of symbionts by solemyid bivalves, as proposed by Imhoff et al. (2003).

Acknowledgements. We greatly appreciate the advice on the taxonomy of solemyids by P. V. Scott and E. V. Coan (Santa Barbara Museum of Natural History, Santa Barbara). We thank P. Linke and N. von Mirbach (IFM-GEOMAR, Kiel) for providing Acharax specimens from the Makran convergent margin, and M. Blümel, F. Lappe, R. Stöhr, and J. Wiese (IFMGEOMAR, Kiel) for methodological advice. The reviewers' qualified comments significantly improved the quality of the data interpretation and manuscript. This study was partly funded by the Deutsche Forschungsgemeinschaft as part of the DFG-Research Center 'Ocean Margins' of the University of Bremen No. RCOM0326. S.C.N. was funded by the German National Academic Foundation.

\section{LITERATURE CITED}

Adamkewicz L, Harasewych MG, Blake J, Saudek D, Bult CJ (1997) A molecular phylogeny of the bivalve mollusks. Mol Biol Evol 14:619-629

Akaike H (1974) A new look at the statistical model identification. IEEE (Inst Elect Elctron Eng) Trans Automatic Control 19:716-723

Anderson AE, Childress JJ, Favuzzi JA (1987) Net uptake of $\mathrm{CO}_{2}$ driven by sulphide and thiosulphate oxidation in the bacterial symbiont-containing clam Solemya reidi. J Exp Biol 133:1-31

Barry JP, Kochevar RE, Baxter CH (1997) The influence of pore-water chemistry and physiology in the distribution of vesicomyid clams at cold seeps in Monterey Bay: implications for patterns of chemosynthetic community organization. Limnol Oceanogr 42:318-328

Bernard FR (1980) A new Solemya s. str. from the Northeastern Pacific (Bivalvia: Cryptodonta). Venus (Jpn J Malacol) 39:17-23

Campbell MR, Steiner G, Campbell LD, Dreyer H (2004) Recent Chamidae (Bivalvia) from the western Atlantic Ocean. Malacologia 46:381-415

Carney RS (1994) Consideration of the oasis analogy for chemosynthetic communities at Gulf of Mexico hydrocarbon vents. Geo Mar Lett 14:149-159

Cary SC (1994) Vertical transmission of a chemoautotrophic symbiont in the protobranch bivalve, Solemya reidi. Mol Mar Biol Biotechnol 3:121-130

Cavanaugh CM (1983) Symbiotic chemoautotrophic bacteria in marine invertebrates from sulphide-rich habitats. Nature 302:58-61

Cavanaugh CM, Abbott M, Veenhuis M (1988) Immunochemical localization of ribulose-1,5-bisphosphate-carboxylase in the symbiont-containing gills of Solemya velum (Bivalvia: Mollusca). Proc Natl Acad Sci USA 85: 7786-7789

Coan EV, Scott PV, Bernard FR (2000) Bivalve seashells of western North America. Santa Barbara Museum of Natural History, Santa Barbara, CA

Conway NM, Howes BL, McDowell Capuzzo J, Turner RD, Cavanaugh CM (1992) Characterization and site description of Solemya borealis (Bivalvia; Solemyidae), another bivalve-bacteria symbiosis. Mar Biol 112:601-613

Distel DL, Felbeck H, Cavanaugh CM (1994) Evidence for phylogenetic congruence among sulfur-oxidizing chemoautotrophic bacterial endosymbionts and their bivalve hosts. J Mol Evol 38:533-542

Eisen JA, Smith SW, Cavanaugh CM (1992) Phylogenetic relationships of chemoautotrophic bacterial symbionts of Solemya velum Say (Mollusca: Bivalvia) determined by 16S rRNA gene sequence analysis. $J$ Bacteriol 174: $3416-3421$

Felbeck H (1983) Sulfide oxidation and carbon fixation by the gutless clam Solemya reidi: an animal-bacteria symbiosis. J Comp Physiol 152:3-11

Fisher CR (1990) Chemoautotrophic and methanotrophic symbioses in marine invertebrates. Rev Aquat Sci 2: $399-436$

Giribet G, Distel DL (2003) Bivalve phylogeny and molecular data. In: Lydeard C, Lindberg DR (eds) Molecular systematics and phylogeography of mollusks. Smithsonian Books, Washington, DC, p 45-90

Giribet G, Wheeler W (2002) On bivalve phylogeny: a highlevel analysis of the Bivalvia (Mollusca) based on combined morphology and DNA sequence data. Invertebr Biol 121:271-324

Gustafson RG, Reid RGB (1988) Association of bacteria with larvae of the gutless protobranch bivalve Solemya reidi (Cryptodonta: Solemyidae). Mar Biol 97:389-401

Imhoff JF, Sahling H, Süling J, Kath T (2003) 16S rDNA-based phylogeny of sulphur-oxidising bacterial endosymbionts in marine bivalves from cold-seep habitats. Mar Ecol Prog Ser 249:39-51

Juniper SK, Tunnicliffe V, Southward EC (1992) Hydrothermal vents in turbidite sediments on a Northeast Pacific spreading centre: organisms and substratum at an ocean drilling site. Can J Zool 70:1792-1809

Krueger DM, Cavanaugh CM (1997) Phylogenetic diversity of bacterial symbionts of Solemya hosts based on compara- 
tive sequence analysis of 16S rRNA genes. Appl Environ Microbiol 63:91-98

Krueger DM, Dubilier N, Cavanaugh CM (1996a) Chemoautotrophic symbiosis in the tropical clam Solemya occidentalis (Bivalvia: Protobranchia): ultrastructural and phylogenetic analysis. Mar Biol 126:55-64

Krueger DM, Gustafson RG, Cavanaugh CM (1996b) Vertical transmission of chemoautotrophic symbionts in the bivalve Solemya velum (Bivalvia: Protobranchia). Biol Bull (Woods Hole) 190:195-202

Kuznetsov AP, Schileyko AA (1984) On gutless Protobranchia (Bivalvia). Biol Nauki 2:39-49

Lee RW, Childress JJ (1994) Assimilation of inorganic nitrogen by marine invertebrates and their chemoautotrophic and methanotrophic symbionts. Appl Environ Microbiol 60:1852-1858

Ludwig W, Strunk O, Westram R, Richter L and 28 others (2004) ARB: a software environment for sequence data. Nucleic Acids Res 32:1363-1371

Métivier B, von Cosel R (1993) Acharax alinae n. sp., Solemyidae (Mollusca: Bivalvia) géante du bassin de Lau. C R Acad Sci Sér III 316:229-237

O'Brien J, Vetter RD (1990) Production of thiosulfate during sulfide oxidation by mitochondria of the symbiont-containing bivalve Solemya reidi. J Exp Biol 149:133-148

Okutani T, Fujikura K (2002) Abyssal gastropods and bivalves collected by Shinkai 6500 on slope of the Japan Trench. Venus (Jpn J Malacol) 60:211-224

Olu K, Lance S, Sibuet M, Henry P, Fiala-Médioni A, Dinet A (1997) Cold seep communities as indicators of fluid expulsion patterns through mud volcanoes seaward of the Barbados accretionary prism. Deep-Sea Res I 44:811-841

Posada D, Buckley T (2004) Model selection and model averaging in phylogenetics: advantages of the AIC and Bayesian approaches over likelihood ratio tests. Syst Biol 53:793-808

Posada D, Crandall KA (1998) MODELTEST: testing the model of DNA substitution. Bioinformatics 14:817-818

Powell MA, Somero GN (1986) Hydrogen sulfide oxidation is coupled to oxidative phosphorylation in mitochondria of Solemya reidi. Science 233:563-566

Sahling H, Rickert D, Lee RW, Linke P, Suess E (2002) Macrofaunal community structure and sulfide flux at gas hydrate deposits from the Cascadia convergent margin. Mar Ecol Prog Ser 231:121-138

Sahling H, Galkin SV, Foerstel H, Greinert J, Piepenburg D, Suess E (2003) Depth-related structure and ecological significance of cold-seep communities - a case study from the Sea of Okhotsk. Deep-Sea Res I 50:1391-1409

Sellanes J, Quiroga E, Gallardo VA (2004) First direct evidence of methane seepage and associated chemosynthetic communities in the bathyal zone of Chile. J Mar Biol Assoc

Editorial responsibility: Otto Kinne (Editor-in-Chief) Oldendorf/Luhe, Germany
UK 84:1065-1066

Sibuet M, Olu K (1998) Biogeography, biodiversity and fluid dependence of deep-sea cold-seep communities at active and passive margins. Deep-Sea Res II 45:517-567

Steiner G, Hammer SE (2000) Molecular phylogeny of the Bivalvia inferred from 18S rDNA sequences with particular reference to the Pteriomorphia. Spec Publ Geol Soc Lond 177:11-2a

Steiner G, Müller M (1996) What can 18S rDNA do for bivalve phylogeny? J Mol Evol 43:58-70

Stoesser G, Baker W, van den Broek A, Garcia-Pastor M and 12 others (2003) The EMBL Nucleotide Sequence Database: major new developments. Nucleic Acids Res 31: $17-22$

Suess E, Carson B, Ritger SD, Moore JC, Jones ML, Kulm LD, Cochrane GR (1985) Biological communities at vent sites along the subduction zone off Oregon. Bull Biol Soc Wash 6:475-484

Suess E, Bohrmann G, Huene RV, Linke P and 6 others (1998) Fluid venting in the eastern Aleutian subduction zone. J Geophys Res 103:2597-2614

Swofford DL (2003) PAUP*. Phylogenetic analysis using parsimony ( ${ }^{*}$ and other methods). Sinauer Associates, Sunderland, MA

Thompson JD, Gibson TJ, Plewniak F, Jeanmougin F, Higgins DG (1997) The ClustalX windows interface: flexible strategies for multiple sequence alignment aided by quality analysis tools. Nucleic Acids Res 24:4876-4882

Vetter RD (1990) Cultured gill filaments from Solemya reidi: a model system for the study of thiotrophic symbioses. In: Nardon P, Gianinazzi-Pearson V, Greneir AM, Margulis L, Smith DC (eds) Endocytobiology. IV. Institut National de la Recherche Agronomique, Paris, p 349-352

von Rad U, Berner U, Delisle G, Doose-Rolinski H and 7 others (2000) Gas and fluid venting at the Makran accretionary wedge off Pakistan. Geo Mar Lett 20:10-19

Waller TR (1990) The evolution of ligament systems in the Bivalvia. In: Morton B (ed) Proceedings of a Memorial Symposium in Honour of Sir Charles Maurice Yonge, Edinburgh, 1986. Hong Kong University Press, Hong Kong, p 49-71

Waller TR (1998) Origin of the molluscan class Bivalvia and a phylogeny of major groups. In: Johnston PA, Haggart JW (eds) Bivalves: an eon of evolution. University of Calgary Press, Calgary, p 1-45

Wiedicke M, Sahling H, Delisle G, Faber E and 6 others (2002) Characteristics of an active vent in the fore-arc basin of the Sunda arc, Indonesia. Mar Geol 184:121-141

Wilmot D, Vetter RD (1992) Oxygen- and nitrogen-dependent sulfur metabolism in the thiotrophic clam Solemya reidi. Biol Bull (Woods Hole) 182:444-453

Submitted: February 23, 2005; Accepted: October 16, 2005 Proofs received from author(s): March 13, 2006 